\title{
ANTIMICROBIAL ACTIVITIES OF HONEY FROM DIFFERENT GEOGRAPHICAL LOCATIONS ON GRAM NEGATIVE AND POSITIVE ORGANISMS
}

OLAWUYI $^{1,2}$, A. K., FASINA ${ }^{1}$, F. O., ARDZARD ${ }^{1}$, S., AKANO ${ }^{1,3}$, G. F., AGADA ${ }^{1}$, G. O. and $\mathrm{GADO}^{1,2}$, D. A.

${ }^{1}$ National Veterinary Research Institute, Vom, Plateau State, Nigeria.

${ }^{2}$ Department of Medical Microbiology, Federal College of Veterinary and Medical Laboratory Technology, Vom, Plateau State, Nigeria.

${ }^{3}$ Department of Microbiology and Virology, Abubakar Tafawa Balewa University, Bauchi, Bauchi State, Nigeria.

*Corresponding author: Email:daydupe2003@yahoo.co.uk; Tel: +2347033128949

\section{SUMMARY}

Honey samples were obtained from the different agro-ecological zones of Nigeria including: the tropical rainforest, mangrove swamp, plateau grassland, guinea savannah and sudan savannah. The antimicrobial activities of these differently sourced honeys were assessed against six bacteria organisms (Staphylococcus aureaus, Escherichia coli, Pseudomonas aeruginosa, Salmonella typhi, Klebsiella aerogenes and Proteus mirabilis). The minimum inhibitory concentration (MIC) and minimum bactericidal concentration (MBC) were studied using standard methods. Results obtained showed that geographical locations had effects on the antibacterial activities of the different honeys at different concentrations $(6.25-100 \%)$. Honey originating from Vom, Plateau State showed the highest antimicrobial activity. All the honeys showed varied bacteriostatic and bactericidal activities. None of the honeys produced any effect on Klebsiella aerogenes and Proteus mirabilis. Further work is encouraged.

KEYWORDS: Honey, Nigeria, antimicrobial, geographical variation.

\section{INTRODUCTION}

Developing countries especially Africa has some of the highest records of human fatalities due to preventable diseases (Sofowora, 1987). Despite the enormous advances in healthcare during the last half century, infectious diseases still account for $25 \%$ of total mortality worldwide and $45 \%$ in low income food deficient countries (LIFDC) (WHO, 1999). Antimicrobial drugs are critically important in reducing the global burden of infectious diseases. However, as resistant microbes develop and spread the effectiveness of such drugs also diminish (WHO, 1999). The growing resistance of micro-organisms to conventional antimicrobial agents is the concern to clinical microbiologist all over the world (Boonmar et al., 1998; Goncagul et al., 2004). As a result, efforts are being intensified to develop antimicrobial agents from other sources 
for better chemotherapeutic effects (Shears, 2000).

Honey, a bye-product of honeybees (Apis mellifera) is one of the ancient traditional medicines used for the treatment and prevention of various diseases. Ancient records confirmed the usage of honey as medicaments (Aristotle, 350 BC; Van Ketel, 1892; Gunther, 1959). In more recent times, the contemporary medical practitioners have rediscovered the use of honey as a therapeutic substance and it is gaining widespread acceptance as an antibacterial agent for the treatment of topical infections resulting from surgical wounds and burns (Kandil et al., 1987; Efem, 1988). Similarly, peptic ulcers and gastritis have been treated with honey while the antibacterial and antifungal properties of honey have been well documented (Haffejee and Moosa, 1985; Molan, 1992a; Al Somai et al., 1994; Abuharfeil et al., 1999). It was also confirmed that honey from a particular regions may have better therapeutic activities (Allen et al., 1991a).

Antimicrobial activity of honey has been attributed to a heat and light labile substance called inhibine, a product of honey glucose oxidase (White et al., 1963). Other workers attributed these bacteriostatic/bactericidal ability to its high osmotic effect, high acidic nature ( $\mathrm{pH}$ 3.2-4.5), high level of hydrogen peroxide concentration and its phytochemical nature which include the following chemicals; tetracycline derivatives, peroxides, amylase, fatty acid, phenols, ascorbic acid, flavonoids, streptomycin, sulfathiazole, triterpenes, benzyl alcohol and benzoic acids.( Molan, 1992a, 1992b).

Although, honey is widely produced and used as food and medicaments in tropical Africa and in Nigeria in particular, their antibacterial activity with reference to geographical origin has never been documented.

This work compared the antimicrobial activities of wet-season/rainy season (May-July) honeys derived from different geographical ecosystems of Nigeria \{Ogbomoso, Oyo State (Tropical rainforest); Semenkpe bush, Bayelsa State (Mangrove swamp); Vom, Plateau State (Plateau grassland); Angwan Mailafia, Kaduna State (Guinea savannah) and Takum, Taraba State (Sudan savannah)\}, against selected Gram negative and positive bacterial organisms (Staphylococcus aureus, Escherichia coli, Pseudomonas aeruginosa, Salmonella typhi, Klebsiella aerogenes and Proteus mirabilis). We also studied the effect of climatic conditions/geography on the antimicrobial properties of the honey collected from the various locations. The minimal inhibitory concentration (MIC) and minimum bactericidal concentration (MBC) of these honeys were determined using standardized methods (Barrow and Feltham, 2004a).

\section{MATERIALS AND METHODS Samples collection}

The following locations were visited for sample collections: Ogbomoso, Oyo state-tropical rainforest; Semenkpe bush, Bayelsa state-mangrove swamp, Takum, Taraba state-sudan savannah, Angwan Mailafia, Kaduna state-guinea savannah and Vom, Plateau state- plateau grassland (Table I). Honeycombs were collected and processed according to the standards in the traditional industry. The honeys were melted from the honeycombs and collected into sterile laboratory glassware, labelled as OgbTR (Ogbomoso-tropical rainforest), Se- 
MS (Semenkpe-mangrove swamp), TaSS (Takum-sudan savannah), Am-GS (Angwan Mailafia-guinea savannah), and Vo-PG (Vom-plateau grassland) and kept at +2 to $+8^{0} \mathrm{C}$ until used (Table 1). The samples were tested for microbial purity by plating each honey on McConkey and blood agar plates and incubation at $37^{\circ} \mathrm{C}$ for 24 hours. Some undiluted portions of the honeys were reserved. Other portions were diluted by thorough homogenization using sterile distilled water to $1: 2(50 \%), \quad 1: 3$ $(33.3 \%), 1: 4(25 \%)$ and $1: 5(20 \%)$ of their original concentrations.

\section{Selection of bacteria isolates}

The clinical isolates of bacterial species most commonly involved in causing gastroenteritis, wound infections, and urinary tract infections were obtained from the culture bank of the Bacteriology Department, Federal College of Veterinary and Medical Laboratory Technology, Vom, Nigeria. Pure culture of each of the isolates was obtained by sub-culturing the isolates on their selective media. Briefly, a colony was picked from the nutrient agar slant containing Staphylococus aureaus obtained from the culture bank and streaked onto Mannitol salt agar. This was incubated at $37^{\circ} \mathrm{C}$ for 24 hours. The organism fermented the Mannitol. Similarly, a colony was picked from nutrient agar slant containing Escherichia coli. This was introduced into MacConkey agar and incubated at $37^{0} \mathrm{C}$ for 24 hours. Smooth pink colonies were seen on the plate post incubation, this was confirmed using Eosin Methylene Blue (EMB) agar on which the organism gave a blue-black, dark centred colony with green, metallic sheen; an indication of E. coli.
Furthermore on a blood agar plate, Pseudomonas aeruginosa was cultured which resulted in large flat haemolytic colonies on the plate 24 hours postincubation. We observed a dark greenish-blue coloration which indicated the diffusing of pigment into the medium. Standard morphological techniques were similarly carried out for the other three organisms (Salmonella typhi, Klebsiella aerogenes and Proteus mirabilis) (Cheesbrough, 2000a). Biochemical tests were performed on each isolate to confirm the identity of the organisms according to standard procedures (Cheesbrough, 2000b; Barrow and Feltham, 2004b).

\section{Preparation of selected bacterial isolates}

Fresh isolates of the morphologically identical pure culture of each test organism was picked from the selective medium. Specifically, three colonies of each of the isolates were picked with an inoculating wire loop, suspended in $5 \mathrm{ml}$ of nutrient broth and incubated at $37^{\circ} \mathrm{C}$ for 3 hours, to reactivate the organisms. This was then diluted with sterile distilled water until a turbidity that matched 0.5 McFarland Standards $\left(10^{6}\right.$ $\mathrm{CFU} / \mathrm{ml}$ ) was reached. The resulting suspension was further diluted 1:100 in sterile nutrient broth to set an inoculum density of $10^{4} \mathrm{CFU} / \mathrm{ml}$ used in the experiment (Woods and Washington, 1995; Miles and Amyes, 1996). The process was repeated until all the isolates were similarly prepared. These dilutions were stored at $+4^{0} \mathrm{C}$ until used same day. 
Table I. Geographical locations of honey and their descriptive features.

\begin{tabular}{|c|c|c|}
\hline Honey (Code) & Source & Description of Source \\
\hline $\begin{array}{l}\text { Ogbomoso, } \\
\text { State (Ogb-TR) }\end{array}$ & $\begin{array}{l}\text { South-West, } \\
\text { Nigeria }\end{array}$ & $\begin{array}{l}\text { The landscape consists of old hard rocks and dome shaped hills, } \\
\text { which rise gently from about } 500 \text { meters in the southern part to } \\
\text { about } 1,219 \text { metre above sea level in the northern part. The mean } \\
\text { annual temperature is } 25-35^{\circ} \mathrm{C} \text { with relatively high humidity. } \\
\text { Annual rainfall is } 1400-1800 \mathrm{~mm} \text { per annum. Tropical rainforest } \\
\text { are the usual fauna. }\end{array}$ \\
\hline
\end{tabular}

Angwan Mailafia, North-West, The State extends from the tropical grassland known as the Kaduna State (Am- Nigeria Guinea Savannah to Sudan Savannah. Vegetation is thick and GS) grasses grow to a height of about 3.6 meters tall with big trees, which grow shorter as one approaches the Sudan Savannah. Mean annual temperature is $27-30^{\circ} \mathrm{C}$ and the annual rainfall is 1000 $1400 \mathrm{~mm}$ per annum.

Vom, Plateau State (Vo-PG)

Semenkpe Bush, South-South, Bayelsa State (Se- Nigeria MS)

Takum, Taraba State (Ta-SS)
North-Central, Nigeria

North-East, Nigeria
Mountainous areas with many rock formations. The grassland altitude ranges from around 1,200metres (4000 feet) to a peak of 1,829 metres. The average temperature is $18-22^{\circ} \mathrm{C}$ and the annual rainfall varies from $1800-2200 \mathrm{~mm}$ per annum.

Riverine and estuarine settings. The terrains are difficult due to large pools of water and often inaccessible roads. Mangrove plants thrive well in this state. Mean annual temperature is 24$27^{\circ} \mathrm{C}$ and the mean annual rainfall is $>4000 \mathrm{~mm}$ per annum

It consists of undulating landscape dotted with a few mountainous features and lies largely within the tropical zone. It has a vegetation of low forest in the southern part and grassland in the northern part. The Mambilla Plateau (located in the state has an altitude of 1,800 meters (6000 ft) above sea level and a temperate climate all year round. The mean annual temperature is $27-30^{\circ} \mathrm{C}$ and the annual rainfall is $1000-1400 \mathrm{~mm}$ per annum

\section{Antimicrobial assay}

Nutrient agar plates were prepared asceptically, allowed to set and dried. One millilitre $(1 \mathrm{ml})$ of the standard inoculum of the previously prepared bacterial isolates was used to flood nutrient agar plates in the agar diffusion method of in-vitro antimicrobial sensitivity test (Bauer et al., 1966). With the aid of the sterile standard cork borer, 7 radial wells of $6 \mathrm{~mm}$ diameter were punched equidistantly at different sites on the plates and the bottoms of the wells were sealed with one drop of the sterile molten nutrient agar. The $6^{\text {th }}$ and $7^{\text {th }}$ wells served as negative (Distilled water) and positive (40 $\mathrm{mg} / \mathrm{ml}$ of Ciprofloxacin) controls respectively. Fifty microlitres $(50 \mu \mathrm{l})$ of each of the honey: undiluted and diluted with sterile distilled water (undiluted-100\%, 50\%, $33 \%, 25 \%$ and $20 \%$ ) from each location were placed in five of the bored wells. The $6^{\text {th }}$ and $7^{\text {th }}$ wells were filled with sterile distilled water (negative control) and Ciprofloxacin (positive control) respectively. This processes were repeated for each honey sample viz OgbTR, Se-MS, Ta-SS, Am-GS and Vo-PG; and for each of the organisms (Table 2). The plates were left on the bench for 40 minutes for pre-diffusion and then 
incubated at $37^{\circ} \mathrm{C}$ overnight. The resulting zones of inhibition (measured in millimetres) were observed for the different concentrations of the honeys.

\section{Minimum Inhibitory Concentration (MIC) and Minimum Bactericidal Concentration (MBC)}

Following the initial antimicrobial screening tests, the minimum inhibitory concentration of each honey was determined by using the broth tube dilution method as described by Barrow and Feltham (2004b).

Twelve sterile test tubes were set for each honey sample. $1 \mathrm{ml}$ of freshly prepared nutrient broth was added to eleven sets of sterile tubes (number 212). This process was repeated seven times to accommodate all the five honeys and the organisms susceptible in the antimicrobial screening assay. $1 \mathrm{ml}$ of the undiluted honeys was transferred into the first set of tubes. Two-fold serial dilutions were performed by transferring $1 \mathrm{ml}$ each of the different undiluted honeys into the second tubes and vortexed for homogenization to give a dilution of 1:2. The process continued until eleventh tubes with a dilution of 1:1024 was reached and $1 \mathrm{ml}$ was discarded. Nothing was added to the last tubes which contained only nutrient broth (controls). One $(1 \mathrm{ml})$ of the standard inoculum of each of the organisms was then added to all tubes.

The entire procedure was repeated for all the organisms that were susceptible to each of the honey sample. The tubes were incubated at $37^{\circ} \mathrm{C}$ for 24 hours and observed visually for turbidity postincubation (matching the nutrient broth negative control). Cultures from the incubated tubes were sub-cultured onto fresh sterile nutrient agar plates and incubated at $37^{\circ} \mathrm{C}$ for 48 hours. The plates were examined for growth to determine the minimum bactericidal concentration (MBC). The MBC is the lowest concentration of honey required to produce a sterile culture.

The plates were scored according to the assessment of Payveld, (1986). These include; no growth (bactericidal); light to moderate growth (bacteriostatic); heavy/luxuriant growth (no effect).

\section{RESULTS}

With the exception of the honey from Vom, spores of Clostridia species were isolated from the other honeys when plated on blood agar and McConkey agar plates. Some of the honeys tested had antimicrobial activity against all the bacteria isolates except Proteus mirabilis and Klebsiella aerogenes (Table II).

Honeys from Vom, Plateau (Vo-PG) and Angwan-Mailafia, Kaduna States (AmGS) showed inhibitory effect against Staphylococcus aureus. Pseudomonas aeruginosa was inhibited by honeys from Vom, Plateau and Takum, Taraba States (Ta-SS). Salmonella typhi was inhibited by honeys from AngwanMailafia, Kaduna and Takum, Taraba States. Only honey from Vom, Plateau State inhibited Escherichia coli. Other honeys showed only partial inhibitory activities (Table II).

For the minimum inhibitory concentration, Vo-PG inhibited $P$. aeruginosa at $6.25 \%$, E. coli at $6.25 \%$ and $S$. aureus at $12.5 \%$ concentrations. Ta-SS inhibited S. typhi at $25 \%$ and $P$. aeruginosa at $12.5 \%$ concentrations. Am-GS was active against $S$. typhi at $12.5 \%$ and $S$. aureus at $6.25 \%$ concentrations (Table III).

Vo-PG, Ta-SS and Am-GS all showed bactericidal effects at $100 \%$ concentration against the inhibited organisms. However, Am-GS have no 
bactericidal effect on $S$. typhi after 48hours of incubation. Vo-PG was bactericidal against Pseudomonas aeruginosa and Staphylococcus aureaus at $50 \%$ concentration; and Am-GS produced similar effect on Staphylococcus aureaus at 50\% concentration too. None of the honey was effective at concentration below $50 \%$ (Table IV).

Table II. Antimicrobial activities of honeys from different geographical locations in Nigeria against Gram positive and negative bacteria organisms

\begin{tabular}{|c|c|c|c|c|c|c|c|c|c|c|c|c|c|c|c|c|c|c|c|c|}
\hline \multirow[t]{2}{*}{$\begin{array}{l}\text { Honey } \\
\text { dilution } \\
s\end{array}$} & \multicolumn{5}{|c|}{$\begin{array}{l}\text { Staphylococcus } \\
\text { aureus } \\
\text { Zone of inhil }\end{array}$} & \multicolumn{5}{|c|}{$\begin{array}{l}\text { Pseudomonas } \\
\text { aeruginosa }\end{array}$} & \multicolumn{5}{|c|}{$\begin{array}{l}\text { Escherichia coli } \\
\text { Zone of inhibition } \\
(\mathrm{mm})\end{array}$} & \multicolumn{5}{|c|}{$\begin{array}{l}\text { Salmonella typhi } \\
\text { Zone of inhibition } \\
(\mathrm{mm})\end{array}$} \\
\hline & $\begin{array}{l}\text { 先 } \\
\frac{1}{1} \\
\frac{6}{00} \\
0\end{array}$ & 足 & $\begin{array}{l}0 \\
\vdots \\
j \\
>\end{array}$ & $\sum_{j}^{\infty}$ & 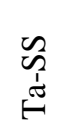 & $\begin{array}{l}\text { 色 } \\
\frac{1}{6} \\
0 \\
0\end{array}$ & 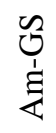 & $\begin{array}{l}0 \\
1 \\
0 \\
1 \\
>\end{array}$ & $\sum_{j}^{n}$ & 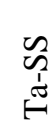 & 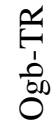 & $\begin{array}{l}0 \\
\vdots \\
\vdots \\
\vdots\end{array}$ & $\begin{array}{l}0 \\
0 \\
0 \\
1 \\
>\end{array}$ & $\sum_{i}^{n}$ & 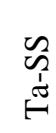 & $\begin{array}{l}\text { 采 } \\
\frac{1}{60} \\
0 \\
0\end{array}$ & $\begin{array}{l}0 \\
\vdots \\
\vdots \\
\vdots\end{array}$ & $\begin{array}{l}0 \\
\vdots \\
0 \\
1 \\
>\end{array}$ & $\sum_{i}^{\infty}$ & \\
\hline $\begin{array}{l}\text { Undilut } \\
\text { ed }\end{array}$ & $\begin{array}{l}1 \\
6\end{array}$ & $\begin{array}{l}\mathbf{1} \\
\mathbf{0} \\
*\end{array}$ & $\begin{array}{l}8 \\
*\end{array}$ & $\begin{array}{l}1 \\
8\end{array}$ & $\begin{array}{l}2 \\
5\end{array}$ & 2 & 5 & $\begin{array}{l}9 \\
*\end{array}$ & 0 & $\begin{array}{l}1 \\
4 \\
*\end{array}$ & $\begin{array}{l}3 \\
0\end{array}$ & $\begin{array}{l}2 \\
0\end{array}$ & $\begin{array}{l}1 \\
4 \\
*\end{array}$ & 20 & 0 & $\begin{array}{l}2 \\
1\end{array}$ & $\begin{array}{l}8 \\
*\end{array}$ & 9 & $\begin{array}{l}2 \\
0\end{array}$ & 9* \\
\hline $1 / 2(50$ & 1 & 1 & 1 & 1 & 1 & 0 & 0 & 7 & 0 & 1 & 2 & 2 & 1 & 20 & 0 & 2 & 1 & 1 & 1 & 11 \\
\hline$\%)$ & 8 & 8 & 7 & 6 & 8 & & & * & & 0 & 0 & 0 & 7 & & & 0 & 0 & 0 & 8 & .2 \\
\hline $1 / 3(33$ & 1 & 1 & 1 & 1 & 1 & 0 & 0 & 7 & 0 & 7 & 2 & 1 & 1 & 15 & 0 & 1 & 1 & 1 & 8 & 8 \\
\hline$\%)$ & 6 & 8 & 5 & 6 & 4 & & & * & & & 0 & 5 & 7 & & & 3 & 0 & 0 & & \\
\hline $1 / 4(25$ & 1 & 0 & 1 & 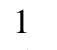 & 1 & 0 & 0 & 9 & 0 & 0 & 1 & 1 & 1 & 14 & 0 & 1 & 0 & 5 & 8 & 0 \\
\hline$\%)$ & 6 & & 5 & 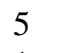 & 0 & & & & & & 8 & 5 & 6 & .5 & & 0 & & & & \\
\hline $1 / 5(20$ & 1 & 0 & 1 & 1 & 1 & 0 & 0 & 0 & 0 & 0 & 1 & 0 & 0 & 0 & 0 & 0 & 0 & 0 & 6 & 0 \\
\hline$\%)$ & 5 & & 0 & 5 & 0 & & & & & & 6 & & & & & & & & & \\
\hline Ciprofl & 1 & 1 & 1 & 1 & 1 & 2 & 2 & 2 & 2 & 2 & 2 & 2 & 2 & 25 & 2 & 1 & 1 & 1 & 1 & 10 \\
\hline oxacin & 5 & 5 & 7 & 5 & 6 & 0 & 0 & 1 & 0 & 2 & 5 & 0 & 5 & $*$ & 5 & 0 & 0 & 0 & 1 & $*$ \\
\hline$(+)$ & $*$ & $*$ & $*$ & $*$ & $*$ & $*$ & $*$ & $*$ & $*$ & $*$ & $*$ & 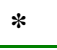 & $*$ & & $*$ & $*$ & $*$ & $*$ & $*$ & \\
\hline $\begin{array}{l}\text { Distille } \\
\text { d water } \\
(-)\end{array}$ & 0 & 0 & 0 & 0 & 0 & 0 & 0 & 0 & 0 & 0 & 0 & 0 & 0 & 0 & 0 & 0 & 0 & 0 & 0 & 0 \\
\hline
\end{tabular}

*complete zone of inhibition; All zones of inhibitions were measured in millimetres; Ogb-TR = Ogbomoso (Tropical rainforest); Am-GS= Angwan Mailafia (Guinea savannah); Vo-PG= Vom (Plateau grassland); Se-MS= Semenkpe Bush (Mangrove swamp); Ta-SS= Takum (Sudan savannah); Only honeys from Kaduna (Am-GS), Vom (Vo-PG) and Taraba (Ta-SS) showed clear antimicrobial activities. Bold numbers indicated clear antimicrobial activities. Other values indicated partial inhibitory activities. No effect of the honeys was observed on Proteus mirabilis and Klebsiella aerogenes. 
Table III: Minimum Inhibitory Concentration (MIC) of honey on selected organisms on nutrient broth culture

\begin{tabular}{|c|c|c|c|c|c|c|c|c|c|c|c|c|c|}
\hline \multirow[t]{2}{*}{ Isolates } & \multicolumn{11}{|c|}{ Dilutions of the honeys } & \multirow[t]{2}{*}{ Honey } & \multirow[t]{2}{*}{ MIC } \\
\hline & Undiluted & $1 / 2$ & $1 / 4$ & $1 / 8$ & $1 / 16$ & $1 / 32$ & $1 / 64$ & $1 / 128$ & $1 / 256$ & $1 / 512$ & $1 / 1024$ & & \\
\hline $\begin{array}{l}\text { Pseudomonas } \\
\text { aeruginosa }\end{array}$ & - & - & - & - & - & + & + & + & + & + & + & $\begin{array}{l}\text { Vo- } \\
\text { PG }\end{array}$ & $1 / 16(6.25 \%)$ \\
\hline $\begin{array}{l}\text { Escherichia } \\
\text { coli }\end{array}$ & - & - & - & - & - & + & + & + & + & + & + & $\begin{array}{l}\text { Vo- } \\
\text { PG }\end{array}$ & $1 / 16(6.25 \%)$ \\
\hline $\begin{array}{l}\text { Staphylococcus } \\
\text { aureus }\end{array}$ & - & - & - & - & + & + & + & + & + & + & + & $\begin{array}{l}\text { Vo- } \\
\text { PG }\end{array}$ & $1 / 8(12.5 \%)$ \\
\hline $\begin{array}{l}\text { Salmonella } \\
\text { typhi }\end{array}$ & - & - & - & + & + & + & + & + & + & + & + & Ta-SS & $1 / 4(25 \%)$ \\
\hline $\begin{array}{l}\text { Pseudomonas } \\
\text { aeruginosa }\end{array}$ & - & - & - & - & + & + & + & + & + & + & + & Ta-SS & $1 / 8(12.5 \%)$ \\
\hline $\begin{array}{l}\text { Salmonella } \\
\text { typhi }\end{array}$ & - & - & - & - & + & + & + & + & + & + & + & $\begin{array}{l}\text { Am- } \\
\text { GS }\end{array}$ & $1 / 8(12.5 \%)$ \\
\hline $\begin{array}{l}\text { Staphylococcus } \\
\text { aureus }\end{array}$ & - & - & - & - & - & + & + & + & + & + & + & $\begin{array}{l}\text { Am- } \\
\text { GS }\end{array}$ & $1 / 16(6.25 \%)$ \\
\hline
\end{tabular}

- = No visible growth (not turbid); + = visible growth (turbid)

Vo-PG= Vom (Plateau grassland); Ta-SS= Takum (Sudan savannah); Am-GS= Angwan

Mailafia (Guinea savannah).

Table IV. Minimum Bactericidal Concentration (MBC) of honey on selected organisms on nutrient agar culture

\begin{tabular}{|c|c|c|c|c|c|c|c|}
\hline \multirow[t]{2}{*}{ Isolates } & \multicolumn{5}{|c|}{ Dilutions of honeys } & \multirow[t]{2}{*}{ Honey } & \multirow[t]{2}{*}{$\mathrm{MBC}$} \\
\hline & Undiluted & $1 / 2$ & $1 / 4$ & $1 / 8$ & $1 / 16$ & & \\
\hline $\begin{array}{l}\text { Pseudomonas } \\
\text { aeruginosa }\end{array}$ & - & - & ++ & +++ & +++ & Vo-PG & $1 / 2(50 \%)$ \\
\hline Escherichia coli & - & + & ++ & +++ & +++ & Vo-PG & $1(100 \%)$ \\
\hline $\begin{array}{l}\text { Staphylococcus } \\
\text { aureus }\end{array}$ & - & - & ++ & +++ & +++ & Vo-PG & $1 / 2(50 \%)$ \\
\hline $\begin{array}{l}\text { Pseudomonas } \\
\text { aeruginosa }\end{array}$ & - & + & +++ & +++ & +++ & Ta-SS & $1(100 \%)$ \\
\hline Salmonella typhi & - & +++ & +++ & +++ & +++ & Ta-SS & $1(100 \%)$ \\
\hline Salmonella typhi & ++ & ++ & +++ & +++ & +++ & Am-GS & $0(0 \%)$ \\
\hline $\begin{array}{l}\text { Staphylococcus } \\
\text { aureus }\end{array}$ & - & - & + & +++ & +++ & Am-GS & $1 / 2(50 \%)$ \\
\hline
\end{tabular}

- = Absence of growth (bactericidal); $+=$ Light growth (bacteriostatic); $++=$ Moderate growth (bacterostatic); $+++=$ Heavy growth (No antimicrobial activity) 


\section{DISCUSSION}

In this study five honey samples from the different agro ecological zones of Nigeria were tested for their antimicrobial activities on some selected bacteria organisms. Honeys from Vom, Takum and Angwan-Mailafia displayed both bacteriostatic and bactericidal properties on both Gram positive and Gram negative bacteria depending on their dilutions. The honey samples showed bactericidal activities against the tested organisms up to the dilutions of $50 \%$. This result is similar to those reported by Nzeako and Hamdi (2000) but is at variance with the report of Willix et al. (1992). Since honey's antimicrobial property is dependent on its water activity - (the free water molecules in honey which is usually between 15 and $21 \%$ ) in part, this will directly affect its osmotic effect. It is then rational to assume that a more diluted honey may have lost its antibacterial ability.

This increased dilution factor may also partially explain why honeys from Ogbomoso, Oyo State and Semenkpe bush, Bayelsa State, locations with heavy rainfalls (over $1400 \mathrm{~mm}$ per annum) does not show full antibacterial activity against any of the organisms tested, however, Vom, Plateau State also have high level of rainfall per annum yet its honey was effective against the tested bacterial organisms. The reason for this is not clearly evident in this study.

Of all the honey samples tested, Vom honey had the highest antimicrobial activity followed by Angwan-Mailafia and Takum. These latter two honeys originated from drier parts of Nigeria that receives less annual rainfalls compared to the other two locations (Table I).

The bactericidal activity of the honeys on Pseudomonas aeruginosa, Salmonella typhi and Escherichia coli was found to be between 50 and 100\% concentration for all the three active honey samples. This agrees with the reports of Kingsley (2001) which found honeys to be effective in wound treatment at higher concentrations. The honeys' bactericidal effect against Staphylococcus aureaus was at 50\% concentration. This organism has been reported to be one of the most sensitive to the effects of honey (Molan, 1992a). This factor can therefore be positively annexed in hospital infection controls in view of the development of many methicillin-resistant Staphylococcus aureus (MRSA) species. Other workers had described the complete inhibition of MRSA at honey concentration of as low as $10 \%$ (Hancock B.M., unpublished findings; Willix et al., 1992; Molan and Betts, 2000). It will be necessary to conduct further study to assess the potentials of Nigerian honeys against MRSA agent.

Although Efem, (1988) reported that Pseudononas aeruginosa was resistant to honey, results from this study contradict this assertion since honeys from Vom and Taraba exerted antimicrobial activity on Pseudomonas aeruginosa which have been known to be resistant to some common antibiotics such as penicillin, chloramphenicol, ampicillin etc due to a combination of factors including: low permeability of its cell wall, genetic capacity to express resistant 
mechanisms, mutation in chromosomal genes which regulate resistance genes, and ability to acquire additional resistance genes from other organisms via plasmids, transposons and bacteriophages (Molan and Betts, 2000; Lambert, 2002).

The variation in the antimicrobial potentials of honeys used in the present study as compared with previous similar studies confirms that the source of the nectars may have contributed to the difference in the antimicrobial activities of honey. The different vegetative zones assessed in this study present with different fauna as well as nectars and pollens available for the honeybees (Apis mellifera) found in such locations. Other reports have confirmed that variation in antibacterial activities of honey can be traced to available nectars and pollens (Allen et al., 1991a, 1991b).

In this study, the chemical components of the antimicrobial substances in the honeys were not estimated except for $\mathrm{pH}$. The $\mathrm{pH}$ which was 4.5, 5.0, 5.5, 6.0, and 6.0, for honeys from Vom, Ogbomoso, Angwan Mailafia, Semenkpe and Takum respectively. These values were low enough to be inhibitory to many pathogens whose $\mathrm{pH}$ for normal growth falls between 7.2 and 7.4. The mimimum $\mathrm{pH}$ required for the growth of E. coli, $S$. typhi and $P$. aeruginosa is 4.3, 4.0 and 4.4 respectively. This unsuitable $\mathrm{pH}$ may have contributed to the antimicrobial effects noticed in this experiment.

That the honeys used in this work had no effect on Klebsiella aerogenes and Proteus mirabilis is in contrast with the report by Molan (1992a) and Subrahmanyan (1991). Reasons for this variance will need to be further explored. Spores of Clostridium species were isolated from the honeys from the various locations with the exception of Vo-PG honey. Hauschild and colleagues (1988), had previously reported that spores of Clostridium botulinum were found in honey. This finding serves as a major limitation to the use of some honeys. However, this limitation is nullified in view of a recent study that use gamma-irradiation to sterilize honey; in that work, the antibacterial activity was intact while Clostridia spores, earlier seeded in the honey before sterilization was completely destroyed (Molan and Allen, 1996). Honeys from Vom, Plateau State therefore hold potentials as a better antimicrobial agent since it presented without Clostridia spores and has the least $\mathrm{pH}$.

In this experiment, attempt was made to assess the value of honeys from some geographical locations within Nigeria as antimicrobial therapeutic agents. It has established that some Nigerian honeys produced by honey bees (Apis mellifera) has both bacteriostatic and bactericidal activity when tested in-vitro.

It will be important to carefully assess the types of flowering plants and trees present in each of the study locations, from which the bees obtain their nectar to produce the honeys. It will also be important to do further study on the dryseason honeys from these locations as well as study the phytochemical components and phenolic contents of honeys from these various locations. These studies will be necessary for purposes of pharmacological standardization and clinical evaluation before these honeys can be recommended for preventative and curative measures against common diseases related to the tested bacterial isolates. 


\section{REFERENCES}

ABUHARFEIL, N., AL-ORAN, R. and ABO-SHEHADA, M. (1999): The effect of bee honey on the proliferitive activity on human B and $\mathrm{T}$ lymphocytes and the activity of phagocytes. Food Agric. Immunol., 11: 169-177.

ARISTOTLE, $(350 \quad$ B.C.). Historia Animalium, Volume I-X. In: Gotthelf, A. (2002): Balme, D. M. (ed.); Cambridge Classical Texts and Commentaries, Number 38 . Cambridge University Press; Cambridge, UK. 628p

ALLEN, K. L., MOLAN, P. C., and REID, G. M. (1991a): A survey of the antibacterial activity of some New Zealand honeys. $J$. Pharmacy and Pharmacol., 43: 817-822.

ALLEN, K. L., MOLAN, P. C. and REID, G. M. (1991b): The variability of the antibacterial activity of honey. Apiacta, 26: 114-121.

AL SOMAI, N., COLEY, K. E., MOLAN, P. C. and HANCOCK, B. M. (1994): Susceptibility of Helicobacter pylori to the antibacterial activity of Manuka honey. J. Royal Soc. Medicine, 87: 9-12.

BOONMAR, BANGTRAKULNONTH, A., PORNRUANGWONG, S., SAMOSORNSUK, S., KANEKO, K. and OGAWA, M. (1998): Significant increase in antibiotic resistance of
Salmonella isolates from human beings and chicken meat in Thailand. Vet. Microbiol., 62: 7380.

BARROW, G. I. and FELTHAM, R. K. A. (2004a): Motility test. In: Cowan and Steel's Manual for the Identification of Medical Bacteria. $3^{\text {rd }}$ Edition. Cambridge University Press, UK, pp 26.

BARROW, G. I. and FELTHAM, R. K. A. (2004b): Antibiotic sensitivity. In: Cowan and Steel's Manual for the Identification of Medical Bacteria, $3^{\text {rd }}$ Edition. Cambridge University Press, UK. 331p.

BAUER, A. W., KIRBY, W. M. M., SHERIRS, J. C. and TURCK, M. (1966): Antibiotic susceptibility testing by standard single disk diffusion method. American $J$. Clin. Pathol., 45: 433-436.

CHEESBROUGH, M. (2000a): Antimicrobial sensitivity testing. In: Cheesbrough, M. (ed). District Laboratory Practice in Tropical Countries. Cambridge University Press, UK, pp 132143.

CHEESBROUGH, M. (2000b): Indole test. In: Cheesbrough M. (ed). District Laboratory Practice in Tropical Countries. Cambridge University Press, UK, pp 67-68.

EFEM, S. E. E. (1988). Clinical Observations on the Wound Healing Properties of Honey British J. Surgery, 75: 679-681. 
GONCAGUL, G., GUNAYDIN, E. and CARLI, K. T. (2004): Antibiotic resistance of Salmonella enteritidis of human and chicken origin. Turkish J. Vet. Anim. Sci., 28: 911-914.

GUNTHER, R. T. (1959): The Greek Herbal of Dioscorides (Translated by Goodyear J, 1655). Hafner N. Y. 1934, reprinted 1959.

HAFFEJEE, I. E. and MOOSA, A. (1985): Honey in the treatment of infantile gastroenteritis. British Medical J., 290: 1866-1867.

HAUSCHILD, A. H. W., HILSHEIMER, R., WEISS, K. F. and BURKE, R. B. (1988): Clostridium botulinum in honey, syrups, and dry infant cereals. $J$. Food Protect., 51: 892-894.

KANDIL, A., ELBANBY, M., ABDELWAHED, K., ABOUSEHLY, G. and EZZAT, W. (1987): Healing effect of the floral and false non-floral honey on medical wounds. J. Drug Research (Cairo), 17: 71-75.

KINGSLEY, A. (2001): The use of honey in the treatment of infected wounds. Case studies. British J. Nursing 10(22): Supplement 13-20.

LAMBERT, P. A. (2002): Mechanism of antibiotic resistance in Pseudomonas aeruginosa. $J$. Royal Soc. Medicine $\mathbf{9 5}$ (Supplement 41): 22-26.
MILES R. S. and AMYES, S. G. B. (1996): Laboratory control of antimicrobial therapy. In: Collee, J G; Fraser, A G; Marmion, B P; Simmons, A (eds). Mackie and McCartney Practical Medical Microbiology, 14th Edition, New York, Churchill Livingstone pp. 151-178.

MOLAN, P. C. (1992a): The antimicrobial activity of honey. I. The nature of antimicrobial activity. Bee World, 73: 5-28.

MOLAN, P. C. (1992b): The antimicrobial activity of honey. II. Variation in the potency of the antimicrobial activity of honey. Bee World, 73: 59-76.

MOLAN, P. C. and Allen, K. L. (1996): The effect of Gamma-irradiation on the antimicrobial activity of honey. J. Pharmacy and Pharmacol., 48: 1206-1209.

MOLAN, P. C. and BETTS, J. (2000): Using honey dressing. The practical considerations. Nursing Times, 96(49): 36-37.

NZEAKO, B. C. and HAMDI, J. (2000): Antimicrobial potential of honey on some microbial isolates. S. $Q$. U. J. for Scientific Res.:(Medical Science), 2: 75-79.

PAYVELD, R. (1986): Studies on the medicinal potentials of Aloe vera locally used for wound dressing and antimicrobial activity. Indian J. Pharmacol. 31(3): 170-172. 
SHEARS, P. (2000): Antimicrobial resistance in the tropics. Trop. Doctor 30(2): 114-116.

SOFOWORA, A. (1987): Medicinal Plants and Traditional Medicine in Africa. John Wiley and Sons. UK, pp 179.

SUBRAHMANYAM, M. (1991): Topical application of honey in the treatment of burns. British $J$. Surgery 78: 497-498.

VAN KETEL, B. A. (1892): Festnummer der Berichten van den Niederlandsche Maastschappij. Bevordering der Pharmacie, 67/96.

WHITE, J. W., SUBERS, M. H. and SCHEPARTZ, A. I. (1963): The identification of inhibine, the antibacterial factor in honey, as hydrogen peroxide and its origin in honey glucose-oxidase system. Biochimica Biophysica Acta, 73: 57-70.

WILLIX, D. J., MOLAN, P. C. and HARFOOT, C. J. (1992): A composition of the sensitivity of wound infecting species of bacteria to the antimicrobial activity of Manuka honey and other honey. J. Applied Bacteriol., 73: 388-394.

WOODS, G. and WASHINGTON, J. A. (1995): Antimicrobial susceptibility test; dilution and disk diffusion methods. Manual of Clinical Microbiology, $6^{\text {th }}$ edition. American Society for Microbiology, Washington, D.C., pp1327-1332.
WORLD HEALTH ORGANISATION. (1999): Drug Information. WHO, Geneva. 13(4): 230-233. 